19 Revue d'histoire du XIXe siècle

Société d'histoire de la révolution de 1848 et des

révolutions du XIXe siècle

$7 \mid 1991$

Sentiment et espaces européens au XIXe siècle

\title{
André Chazal, époux de Flora Tristan : un prisonnier réformateur
}

Jean-Claude Vimont

\section{OpenEdition \\ Journals}

Electronic version

URL: http://journals.openedition.org/rh19/55

DOI: $10.4000 /$ rh 19.55

ISSN: 1777-5329

Publisher

La Société de 1848

Printed version

Date of publication: 1 June 1991

ISSN: 1265-1354

Electronic reference

Jean-Claude Vimont, "André Chazal, époux de Flora Tristan : un prisonnier réformateur », Revue d'histoire du XIXe siècle [Online], 7 | 1991, Online since 09 September 2008, connection on 01 May 2019. URL : http://journals.openedition.org/rh19/55 ; DOI : 10.4000/rh19.55

This text was automatically generated on 1 May 2019.

Tous droits réservés 


\section{André Chazal, époux de Flora Tristan : un prisonnier réformateur}

Jean-Claude Vimont

\section{ABSTRACTS}

No abstract available by now

Pas de résumé disponible actuellement

INDEX

Mots-clés: Tristan Flora 